Japan. J. Med., Sci. Biol., 23, 243-248, 1970

\title{
AN OUTBREAK OF TYPE B BOTULISM OCCURRING IN MIYAZAKI PREFECTURE
}

\author{
Takeo FUKUDA, Tadatoshi KitaO, Hirotoshi TANIKAWA \\ AND GENJI SAKAGUCHI* \\ Miyazaki Prefectural Public Health Laboratory, 5-30 Kita Takamatsu-cho, \\ Miyazaki-shi, Miyazaki 880, Japan \\ * Laboratory of Veterinary Public Health, Department of Veterinary Science, \\ College of Agriculture, University of Osaka Prefecture, \\ Mozu Ume-machi, Sakai-shi, Osaka 591, Japan
}

(Received: July 16th, 1970)

SUMMARY : An outbreak of type B botulism occurred in Miyazaki Prefecture in August, 1969. There were 21 cases of which three resulted in death of patients. This was the first outbreak of human botulism of a type other than type $\mathrm{E}$ in Japan. Type B toxin was demonstrated in fecal specimens; Clostridium botulinum typa B was isolated from a single patient. Bottled caviar imported from West Germany was most strongly suspected of being the vehicle.

\section{INTRODUCTION}

The first bacteriologically proven outbreak of botulism in this country occurred at Iwanai, Hokkaido, in 1951 due to eating herring izushi, from which Clostridium botulinum type E was isolated (Nakamura, Iida and Saeki, 1952). During the period of between 1951 and August, 1969, at least 62 outbreaks of type E botulism were reported from Hokkaido and four northern-most prefectures, viz., Aomori, Akita, Iwate and Yamagata. In an outbreak occurring in Aomori in 1956, type $\mathrm{E}$ toxin was demonstrated in the incriminated izushi but the strain of $C$. botulinum isolated from it was identified to be type B (Nakamura et al., 1963).

Extensive surveillances conducted in this country detected type E spores very frequently in soil, lakeshore mud, costal sand and fish specimens collected from most of the endemic areas and less frequently in those collected in Tokyo (Kobayashi, 1961) and Yamaguchi Prefectures (Yamagata, 1963). Type A spores were also found in soil samples collected in Kagoshima (Wakamatsu, 1952), Nagasaki (Nohtomi, 1957) and Akita Prefectures (Kodama et al., 1963). No report has ever dealt with isolation of type B spores in soil or other environmental specimens collected in this country.

In August, 1969, an outbreak of botulism occurred in Miyazaki Prefecture. There were 21 cases of which 3 ended in patients' death. Type B toxin was

福田武夫・北尾忠利・谷川博利（宮崎市北高松町 5-30 宮崎県衛生研究所）

阪口玄二 (堺市百舌鳥梅町 大阪府立大学農学部獣医学科) 
detected only in fecal specimens, from which $C$. botulinum type B was isolated. Although unavailable for laboratory examination, German-bottled caviar appeared to be the most suspicious vehicle.

\section{Features of the OUtbreak}

On August 21, 1969, there was a reception in Miyazaki City after a conference attended by officials representing all cities, towns and villages in the Prefecture. Sixty-five attendants partook of sake and assorted hors d'oeuvres; 21 of them fell ill after 14 to $49 \mathrm{hr}$ or with an average incubation period of $31 \mathrm{hr}$. Three died on the 3rd, 6th and 9th days after the reception. Diarrhea and vomiting preceded such typical nervous symptoms as diplopia, disphonia, disphagia and respiratory impairment. The cases were scattered all over the Prefecture and the physicians who had seen the patients hardly thought of botulism, thus causing delayed notification of food poisoning. Systematic examinations were started when 4 days had passed from the occurrence of the first patient.

\section{LABORATORY FINDINGS}

\section{Examinations of incriminated foodstuffs and specimens from patients.}

The assorted hors d'oeuvres were incriminated. They involved 10 items, viz, caviar canape, boiled eggs, smoked salmon, processed cheese, roasted pork, fried chicken, Vienna sausage, salame, crab-meat pies and vinegared fried fish. Many of the items were heated shortly before served to such an extent that preformed toxin, if there had been any, would be destroyed completely. Statistical analyses of the data on consumption of each item by 63 affected and nonaffected participants decisively ruled out other items than caviar canape as the possible vehicle. Remnants or the emptied bottles of caviar, however, were no longer available for laboratory tests. Tests for botulinum toxin and $C$. botulinum were performed on 6 items that had been saved and unopened bottles of caviar of the same label as those used for preparing the canape. No toxin was found in the extract nor in the cultures of any of the items.

Thirteen serum specimens from 11 nonfatal patients taken on the 5th-7th days of illness were injected intraperitoneally into mice; no mice developed any symptoms.

Three vomit specimens from 3 patients including one from a fatal case and 21 fecal specimens from 10 nonfatal patients were subjected to laboratory tests. Each specimen was homogenized in about 10 volumes of $0.1 \mathrm{M}$ phosphate buffer, $\mathrm{pH} 6.0$, containing streptomycin at 200 or $400 \mathrm{mcg} / \mathrm{ml}$ and allowed to stand overnight under refrigeration. They were clarified by centrifugation at $3,000 \mathrm{rpm}$ for $30 \mathrm{~min}$. The supernatant fluid was injected intraperitoneally into mice in $0.5 \mathrm{ml}$ amounts. Fecal specimens from 3 patients taken at different times killed mice after manifestation of typical botulism symptoms (Table 1). The toxin in these specimens was neutralized with type $\mathrm{B}$ antitoxin but not with type $\mathrm{A}$ or $\mathrm{E}$ serum and became inoxious upon heating for $80 \mathrm{C}$ for $20 \mathrm{~min}$. One patient continually excreted toxic feces for at least 19 days after the toxic meal. The specimen taken from this patient on the 6th day showed a toxin potency of ap- 
proximately $320 \mathrm{LD}_{50} / \mathrm{g}$.

Isolation of $C$. botulinum was attempted by inoculating a portion of each specimen of vomit or feces into tubes of cooked meat medium (Difco), which were then heated at $60 \mathrm{C}$ for $60 \mathrm{~min}$ and incubated at $30 \mathrm{C}$. On the $2 \mathrm{nd}$ and 5 th days, each culture was streaked out onto glucose blood agar plates; the plates were incubated anerobically for 2 days at $30 \mathrm{C}$. C. botulinum type B was eventually isolated from 2 specimens from one of the patients (Table 1) obtained on the 12th and 13th days by applying enemas. Neither toxin nor C. botulinum type B was detected in any vomit specimen.

Table 1. Detection of the toxin and C. botulinum type B in fecal specimens of nonfatal cases

\begin{tabular}{|c|c|c|c|c|c|c|c|}
\hline \multirow{2}{*}{$\begin{array}{l}\text { Days after } \\
\text { consumption }\end{array}$} & \multicolumn{3}{|c|}{ Patient A } & \multicolumn{2}{|c|}{ Patient $\mathrm{N}$} & \multicolumn{2}{|c|}{ Patient $\mathrm{K}$} \\
\hline & Toxin & $\mathrm{LD}_{50} / \mathrm{g}$ & Organisms & Toxin & Organisms & Toxin & Organisms \\
\hline 6 & + & 320 & - & + & - & + & - \\
\hline 7 & $\ldots$ & $\ldots$ & $\ldots$ & $\ldots$ & $\ldots$ & $\ldots$ & $\ldots$ \\
\hline 8 & + & 60 & - & $\ldots$ & $\ldots$ & $\ldots$ & $\cdots$ \\
\hline 9 & $\ldots$ & $\ldots$ & $\ldots$ & + & - & $\cdots$ & $\cdots$ \\
\hline 12 & $\ldots$ & $\ldots$ & $\ldots$ & + & + & $\cdots$ & $\cdots$ \\
\hline 13 & + & 20 & - & + & + & $\cdots$ & $\cdots$ \\
\hline 14 & + & 30 & - & + & - & $\ldots$ & $\ldots$ \\
\hline 15 & + & 20 & - & $\cdots$ & $\cdots$ & $\cdots$ & $\cdots$ \\
\hline 19 & + & 20 & - & $\cdots$ & $\cdots$ & $\cdots$ & $\cdots$ \\
\hline
\end{tabular}

... No specimen was available.

\section{Main characteristics of the isolated strain.}

The two isolates from fecal specimens were proved to be of the same biological and biochemical characteristics. The organisms were gram-positive rods with oval, subterminal spores considerably distending the sporangia. They grew well on glucose blood agar plates forming flat, transparent, round colonies or translucent colonies with slightly raised centers with a sign of hemolysis. They showed a tendency to swarm on moist surfaces of the plates. Mannose, sucrose and adonitol were not fermented, but salicine fermented; gelatin and coagulated serum liquefied; Negler reaction positive; hydrogen sulfide formed; indole not formed; nitrites not formed from nitrates.

3. Toxin production by the strain in caviar.

The German producer of the caviar stated that their products had been added with salt at $6 \%$. We found the actual $\mathrm{NaCl}$ contents of 5 bottles of caviar of the same batch seized in Miyazaki City ranged from 3.5-5.4\%.

Spores of the isolated strain, after being washed once with the phosphate buffer and heat-treated at $80 \mathrm{C}$ for $20 \mathrm{~min}$, were inoculated into each bottle in an inoculum size of about 140,000 spores/g. The contents of all bottles were found to be lethal for mice after incubation at $33 \mathrm{C}$ for 37 days. One bottle contained 
type B toxin of approximately $10,000 \mathrm{LD}_{50} / \mathrm{g}$.

In separate experiments, $\mathrm{NaCl}$ tolerance of the strain was tested in GAM semi-solid medium (Nissui Seiyaku Co., Tokyo) added with $\mathrm{NaCl}$ at various concentrations after incubation at $33 \mathrm{C}$ for 15 days. In the medium added with $\mathrm{NaCl}$ at $4 \%$ or lower concentrations, abundant growth and toxin production occurred (Table 2). Both growth and toxin production were markedly suppressed by $6 \%$ $\mathrm{NaCl}$ and completely inhibited by $7 \% \mathrm{NaCl}$. These results are well consistent with the positive toxin production in the caviar whose $\mathrm{NaCl}$ contents were $5.4 \%$

Table 2. Growth and toxin production by $C$. botulinum type B strain $\mathrm{BMN}-2$ in response to $\mathrm{NaCl}$ concentrations added to GAM semisolid medium ${ }^{1)}$

\begin{tabular}{cccccccc}
\hline$\% \mathrm{NaCl}$ added & 0.3 & 4 & 5 & 6 & 7 & 8 \\
\hline \multirow{2}{*}{ Growth } & & $\#$ & $\#$ & $\#$ & + & - & - \\
\multirow{3}{*}{ Toxin } & $\times 2$ & $\mathrm{DD}^{2)}$ & D D & D D & D D & S S $^{2)}$ & S S \\
& $\times 100$ & D D & D D & S S & S S & S S & $\cdots$ \\
\hline
\end{tabular}

1) Toxicity tests were performed after incubating the cultures at $33 \mathrm{C}$ for 15 days. Dilution was made in $0.1 \mathrm{M}$ phosphate buffer, $\mathrm{pH}$ 6.0. Each dilution was injected intraperitoneally into 2 mice in $0.5-\mathrm{ml}$ amounts.

2) D: Death within 4 days, S: Survival at least for 4 days.

\section{DISCUSSIONS}

This was the first outbreak of botulism in Kyushu, the southern-most part of Japan and was the first type B outbreak in Japan. Before the toxin type was diagnosed, type $\mathrm{E}$ antitoxin of 6,000 to 20,000 international units had been administered to 6 patients of serious illness; 2 of them died. The other fatal case did not receive the antitoxin. When we obtained types A and B polyvalent antitoxin of Lederley made on September 2, two patients were still seriously ill. One of them showed too strong skin reaction to the antitoxin; the other received 10,000 international units each of types A and B antitoxin. Both survived. This outbreak strongly points to the necessity for production of polyvalent antitoxin of at least types $\mathrm{A}, \mathrm{B}$ and $\mathrm{E}$ in this country.

The caviar canape appeared to be the most suspicious causative foodstuff among the ten items of the assorted hors d'oeuvres from the following considerations :

1) Statistical analyses of morbidities among 63 participants from consumption of each item of hors d'oeuvres found a very large $\chi^{2}$ value, 12.43 , for caviar canape and a $\mathrm{P}$ value smaller than $0.1 \%$. All the other items except processed cheese $\left(\chi^{2}=3.4\right)$ gave $\chi^{2}$ values below the decimal point or insignificant for calculation of $\chi^{2}$ values. 2) According to the German producer, the caviar had been pasteurized at $80 \mathrm{C}$ for $35 \mathrm{~min}$, which apparently was insufficient to kill the spores of the isolated type B strain. 3) The labels on the bottles indicated that the caviar did not contain any preservatives and that it was necessary for the bottles to be kept under refrigeration. Nevertheless, they had actually been ex- 
posed to high temperature during the summer season for more than three months at retail shops. 4) No heating process had been applied to caviar before preparing canape. 5) Although the German producer stated that $\mathrm{NaCl}$ had been added to the caviar at $6 \%$, the actual contents of $\mathrm{NaCl}$ determined by chemical analyses were lower than $6 \%$, being different from one bottle to another. The fact may indicate insufficient mixing of the product before bottling. Actual growth and toxin production by $C$. botulinum type B in the caviar were demonstrated experimentally. The low morbidity and mortality of the present outbreak may indicate that one bottle ( $50 \mathrm{~g}$ contents) only of the two and half bottles used for preparing canape to serve to 65 persons had been botulinogenic.

Kob (1905) described the detection of botulinum toxin of an unknown type in circulating blood of a patient 9 days after ingestion of toxic food. Demonstration of type E toxin in circulating blood was described by Rogers et al. (1964). We did not succeed in detecting the toxin in serum specimens of patients 5-7 days after the onset of illness. Since all the specimens were obtained from nonfatal cases, the amount of toxin ingested may have been too small to be detected in serum.

On the other hand, detection of the toxin in fecal materials of nonfatal patients was successful. One of the patients excreted toxic feces even 19 days after ingestion of the toxic food. Isolation of $C$. botulinum type B from feces of a patient on the 6th day of illness was reported by Wheeler et al. (1924). It is, however, generally regarded to be a very difficult task to isolate $C$. botulinum from fecal materials. We succeeded in isolating $C$. botulinum type B from fecal materials of a patient taken on the 11th and 12 days of illness. Examinations of as many materials as possible along the course of illness may have brought the success. Attempts at examinations for botulinum toxin and organisms in fecal materials may no doubt be rewarding, particularly when no food specimen is available or even when blood serum is nontoxic.

\section{REFERENCES}

Ков, M. (1905): Beitrag zur Kenntnis des Botulismus. Medizinische Klinik, 4, 84-86.

KoBAYASHI, S. (1961): Investigation on the geographical prevalence of Clostridium botulinum in the eastern part of Japan. Hirosaki Med. J., 12, 682-694.

Kodama, E., Fujisawa, S., Sakamoto, T., Asano, H. and Eto, J. (1963): Über den $C l$. botulinum Typus A, der in der Akita Präfektur Gefunden Wurde. Hirosaki Med. J., 14, 156-164.

Nakamura, G., Takeya, M., Kudo, H., Izumiyama, C., Yamamoto, K., Asano, H. and Takeyama, M. (1963): Ein Fall von Typus B-Botulismus. Hirosaki Med. J., 14, 123127.

NAKAMURA, Y., IIDA, H. AND SAEKI, K. (1952): On botulisms occurring at Shimano, Iwanai-gun, Hokkaido. Spec. Rep. Hokkaido Inst. Publ. Health, 1, 1-18. (text in Japanese).

NoнтомI, T. (1957): Distribution of spores of pathogenic Clostridia in soil samples collected in Nagasaki Prefecture, with special reference to Clostridium botulinum. Nagasaki Med., J., 32, 315-326 (text in Japanese).

Rogers, D. E., Koenig, M. G. AND Spickard, A. (1964): Clinical and Laboratory manifestations of type E botulism in man. "Botulism" (K. H. Lewis and K. Cạssel, Jr., ed), 
U. S. Public Health Service Publication No. 999-FP-1, Cincinnati, Ohio.

WAKAMATSU, T. (1953): Ecological study of Clostridia in Kyushu, especially in its southern part. Kitasato Arch. of Expt. Med., 52, 163-186.

WHEEler, M. W. AND HAMPHRAYS, E. (1924): Isolation of B. botulinum, type B, from feces by use of blood agar plates in anaerobic jar. J. Inf. Dis., 35, 305-310

YAmagata, H. (1963): Distribution of pathogenic Clostridia (Cl. welchii and Cl. botulium) in soil. Rep. Yamaguchi Prefectural Res. Inst. Health, 1, 101-106 (text in Japanese). 